\title{
咽喉頭狭窄をきたした再発性難治性口腔咽頭潰瘍の一症例
}

$\begin{array}{lllr}\text { 金子まどか, } & \text { 長原 太郎, } & \text { 古川 } & \text { 滋 } \\ \text { 古川 政樹, } & \text { 持松いづみ, } & \text { 大石 } & \text { 公直 } \\ \text { 澤木 修二 } & & & \end{array}$

\section{A Case of Pharyngo-laryngeal Stenosis in Reccurent Aphthous Stomatitis}

\author{
Madoka Kaneko, M.D., Taro Nagahara, M.D., Shigeru Furukawa, M.D., \\ Masaki Furukawa, M.D., Izumi Mochimatsu, M.D., Kiminao Ooishi, M.D., \\ and Shuji Sawaki, M.D.
}

Department of Otolaryngology, School of Medicine, Yokohama City University, Yokohama

A 43-year-old female, who had been suffered from the recurrent aphthae for about two years, visited our otolaryngology clinic on April 18, 1985, with complaints of the dysphagia and swallowing pain.

One year later, the dyspnea appeared due to the stenosis of the hypopharynx and the swelling of the epiglottis, followed by an ulcerating mucosal lesion.

She was admitted to our hospital on June 5,1986 . The emergency tracheostomy and intravenous administration of the steroid hormone and antibiotics were performed. After these treatments, the swelling of the hypopharynx was improved, but the stenosis was remained. Surgical correction of the stenotic hypopharynx was accomplished under the laryngo-microsurgery using $\mathrm{CO}_{2}$ LASER, and the dyspnea was improved.

Although the recurrent aphthous stomatitis is not so uncommon disease, the secondary stenosis of the pharynx and larynx is very rare.

The cause, pathology and therapy of this type of aphthous lesion were briefly reviewed.

Key words : 再発性口腔咽頭潰瘍, 下咽頭狭窄, 喉頭狭窄, $\mathrm{CO}_{2}$ レーザー, 喉頭微細手術

\section{1.はじめに}

再発性で難治性の口腔・咽頭潰瘍はしばしば 報告されているが, 潰瘍のあとの洀痕から咽・ 喉頭の狭窄をきたすことは比較的稀である。今 回われわれは多発性の口腔・咽頭潰瘍を繰り返

横浜市立大学医学部耳鼻咽喉科学教室

別刷請求: = 232 神奈川県横浜市南区浦舟町3-46 横浜市立大学医学部耳鼻咽喉科学教室 金子まどか

投稿受付：1988年 1 月20日
し, 約 2 年間の経過ののち喉頭蓋の変形と咽 頭・喉頭の狭窄のため呼吸困難をきたし, レー ザー手術による喉頭蓋形成で狭窄症状の寛解を みた症例を経験したので，その経過を述べると ともに，若干の文献的考察を加えて報告する。 また本疾患の病態には不明な点が多く，のち に皮虐症状や眼症状などを伴い, ベーチェット 病に発展するものもあり，全身的な疾患として 取り扱う必要があるとされている。本疾患の病 態および治療に関しても，文献的考察を加えて 言及する。 


\section{2. 症例}

患 者: 43歳, 女性

主 訴：舌痛, 嚥下困難, 咽頭異常感

初 診：昭和60年 4 月 18 日

既往歴：特記すべきことなし

家族歴：特記すべきことなし

現病歴：昭和 58 年ごろより口内炎を繰り返す ようになり, 徐々に増悪した。昭和 59 年には嬩 下障害が出現し, 以後しだいに増強した。昭和 60 年 2 月さらに嚥下痛と発熱を伴い, 近くの耳 鼻咽喉科医で治療をうけていたが，改善しない ため当科に紹介された。

初診時現症：体格中等度で, やや瘦せぎみ, 栄養状態は普通であった。局所所見のほかには 胸部, 腹部, 四肢に異常を認めなかった。初診 時両側舌縁の多発性アフタと, 中咽頭右側壁に 白苔を伴う広範な潰瘍性病変が認められた（図 1)。また造影 X 線検查では中咽頭後壁の不整像 がみられたが, 下咽頭はほほ正常であった（図 2 )。

初診時の血液検査で膠質反応が上昇し, CRP
が疑陽性で, IgA が軽度上昇し, また $\mathrm{HB}_{\mathrm{s}}$ 抗原 陽性, $\mathrm{HB}_{\mathrm{e}}$ 抗体陽性であった。その他には異常 は認められなかった（表 1 )。

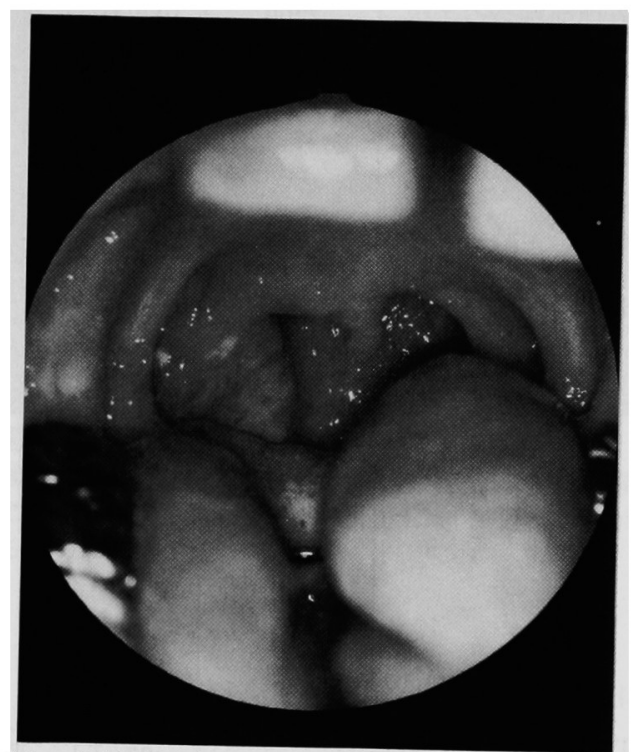

図 1 初診時咽頭所見

中咽頭右側壁に白苔を伴う潰瘍性病変が認められ た。

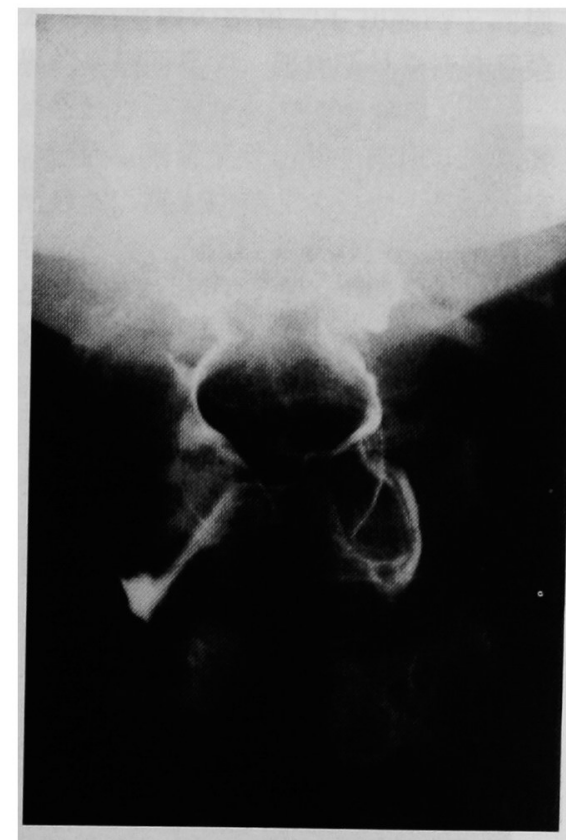

正面

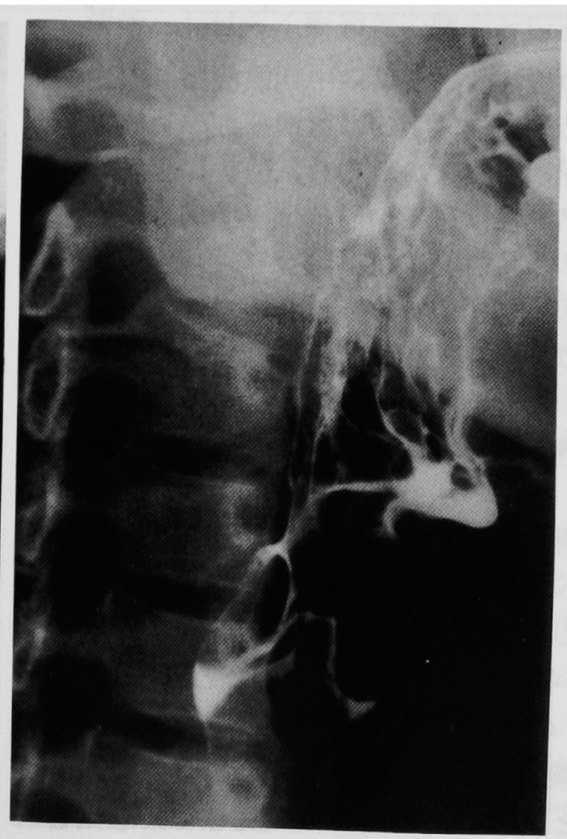

斜 位

図 2 初診時造影 $\mathrm{X}$ 線検査 中咽頭後壁の不整像がみられた。 
表 1 検查結果

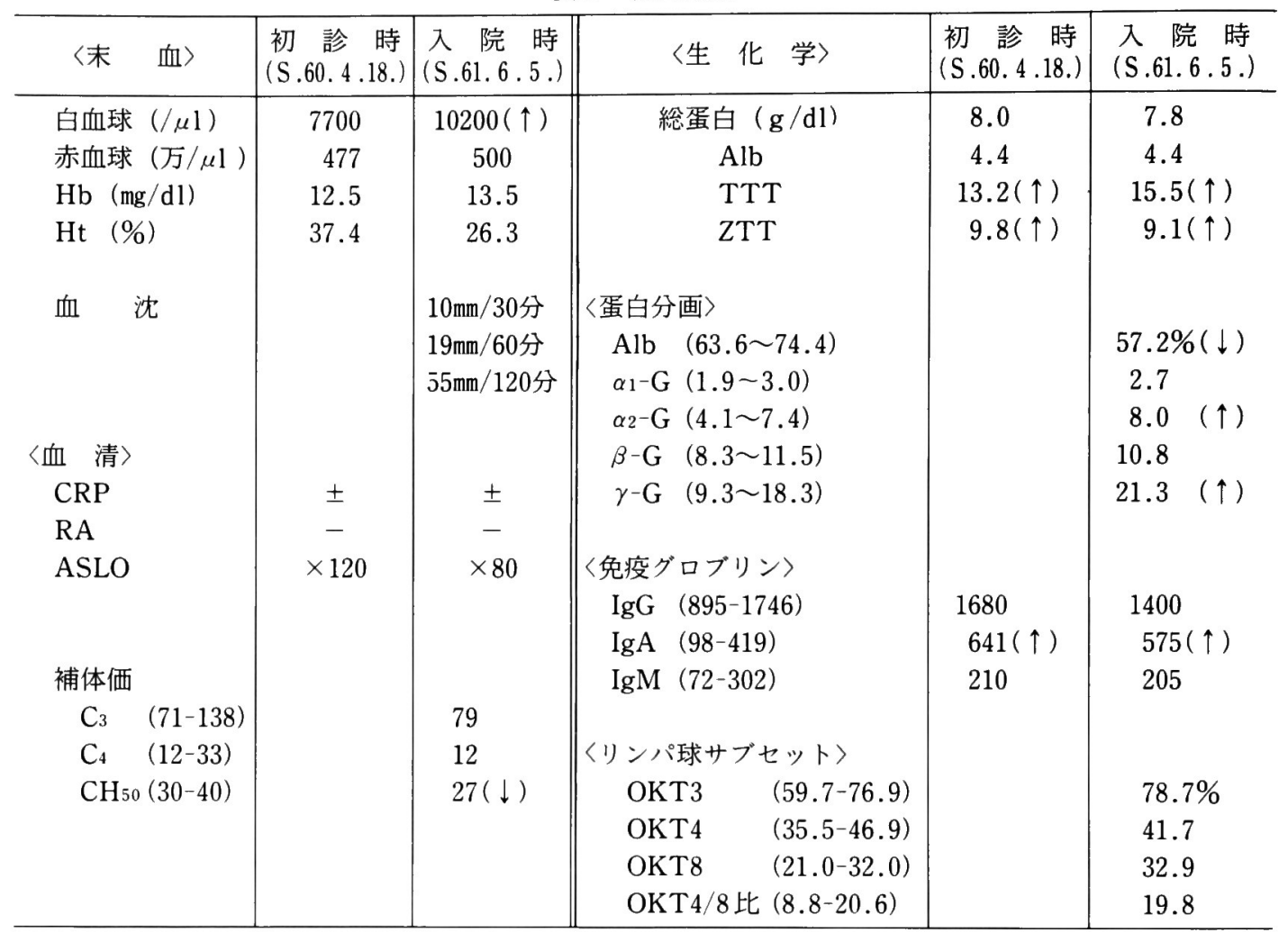

中咽頭の悪性腫湯を疑い中咽頭潰場部の生検 を行った結果, 病理学的には潰瘍性の炎症で悪 性所見は認められなかった（図 3 )。口腔粘膜の 再発性アフ夕性潰瘍でベーチェット病も疑われ たが，皮膚科，眼科の検查所見から否定された。 ステロイドの局所塗布で経過をみたところ，約 1 力月後には所見・症状ともに軽快した。

その後しばらく患者は来院しなかったが, 昭 和61年 6 月 5 日呼吸困難を訴えて当科に再来し た。

再来時所見：ふくみ声で，中咽頭右側壁の潰 瘍が下方へ広がり, 下咽頭・喉頭まで達し, 喉 頭蓋が著しく腫脹し，喉頭の入口部をほとんど 閉塞していた(図 4)。この時の血液ガス分析結 果では, とくに異常所見は認められなかったが, これ以上喉頭蓋の腫脹が進行すると窒息死の危 険があると判断し，ただちに入院して緊急気管

図 3 潰瘍部の病理組織

潰瘍性の炎症で悪性所見は認められない。(H\&E染 色 $\times 40)$

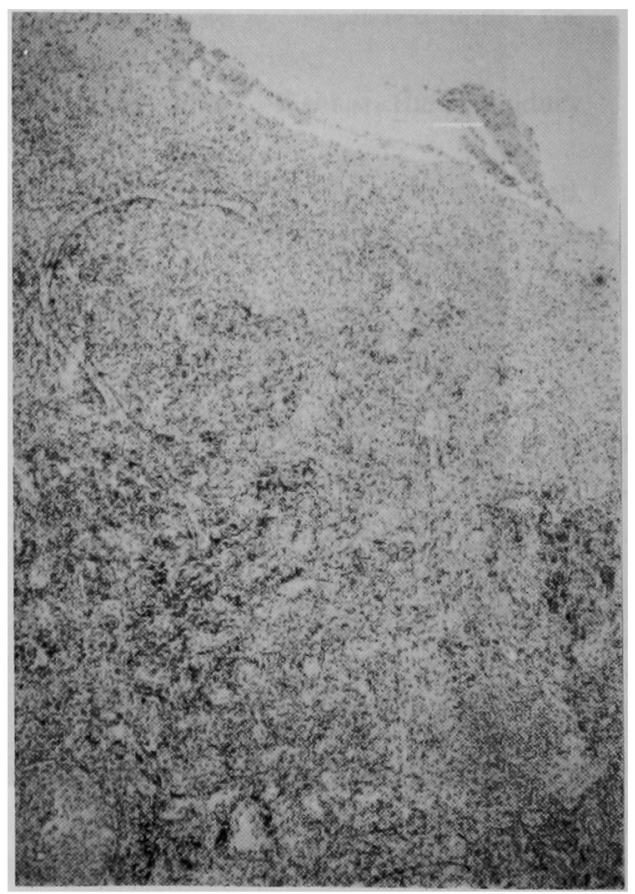




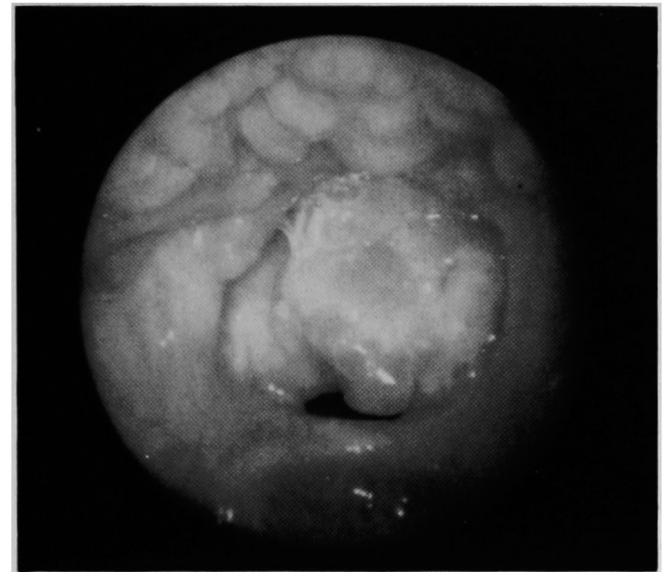

図4 再来時下咽頭・喉頭所見

喉頭蓋が著しく腫脹し, 喉頭の入口部を閉塞してい る。

切開を施行した。

入院時の検査結果 : 軽度の白血球増加と血沈 の六進を認めた。CRP 峐疑陽性であった。膠質 反応と IgA は初診時と同様に高值で, $\alpha_{2}$-およ び $\gamma$-グロブリンも高值であった。全身的な疾患 の可能性も示唆されたが, 血清補体価はやや低 值で，抗核抗体は認められなかった（表 1 )。

喉頭蓋からの生検の結果でも初診時と同様 に, 非特異的炎症所見で, 悪性所見や特殊感染 症像は認められなかった。

入院時の経過：緊急気管切開を施行して気道 を確保したのち, 抗生物質とステロイドを点滴 で全身投与したところ, 喉頭蓋の腫脹は徐々に 軽快したが, 炎症症状が改善するにしたがって 下咽頭に痏痕が形成された。喉頭蓋が咽頭側壁 と瘢痕性に癒着し可動性が失われ, 咽頭腔全体 も瘢痕性に逆円錐状に狭窄し, 喉頭蓋の先端の 部分にかろうじて腔が残るだけになった（図 5 )。喉頭ファイバースコープでこのわずかな腔 より声門を観察したところ, 披裂部と声帯の可 動性は良好で, 声門のレベルまでは瘢痕性の狭 窄が及んでいないことが確かめられた。

造影 X線検査では㗋頭蓋が変形し, 透視下に 喉頭蓋の可動性が失われているのがわかった (図 6 )。

また呼吸機能検査では 1 秒率が $64 \%$ で閉塞性 パターンで, フロー・ボリューム曲線では吸気 でのカーブの平坦化がみられ, 上気道狭窄を示

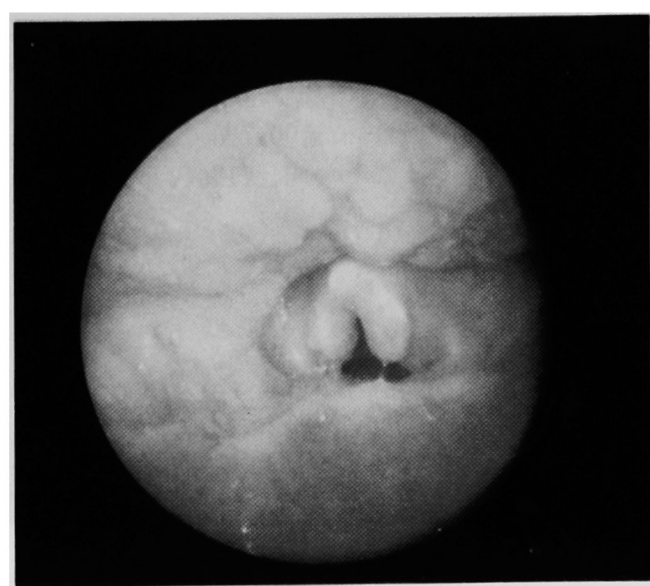

図 5 喉頭蓋形成手術前の下咽頭・喉頭所見 喉頭蓋が咽頭側壁と瘾着し, 咽頭腔全体も逆円錐状 に狭窄し, 喉頭蓋の先端の部分にかろうじて腔が残 るだけになった。

\section{していた（表 2 )。}

この喉頭蓋レベルでの狭窄を開大するために 全身麻酔下に顕微鏡下喉頭微細手術（laryngomicrosurgery）を施行し, $\mathrm{CO}_{2}$ レーザーで喉 頭蓋と咽頭壁との瘾着を切り離し, 瘢痕を切除 して喉頭蓋を形成した。

術後, しばらく喉頭蓋の腫脹と白苔の付着が みられ, 瘢痕と手術操作による循環障害のため かなかなか腫脹が軽快しなかったが，ステロイ ド剤と抗生剂の全身投与を続け, 術後 3 週目に 喉頭蓋の腫脹が改善し, 後方の空隙が開大して いるのが認められた（図 7 )。

この手術によって自覚的にも呼吸困難が改善 したが再発のおそれがあり, 患者の希望もあっ たため気管切開孔は閉鎖せず，スピーチ・カニ ユーレを装着したまま術後 4 週目に退院した。

また，本疾患が食物アレルギーや，口腔内の 歯科治療用金属へのアレルギーによっておこる 可能性を考え，一般的な食物アレルゲンに対す る反応を RAST 法で, また歯科治療用の金属各 種についての皮膚パッチテストを行って調べた が，特異的な反応は見られなかった。

その後も外来で経過観察中であるが, 口腔・ 咽頭の潰瘍は軽快と増悪を繰り返している。外 来での治療としては, ステロイド剤の局所塗布 が主な治療方法で, 増悪時には内服させていた。 しかしステロイド剤も，たとえ局所塗布だけで 
日気食会報，39（4）, 1988

表 2 呼吸機能検查

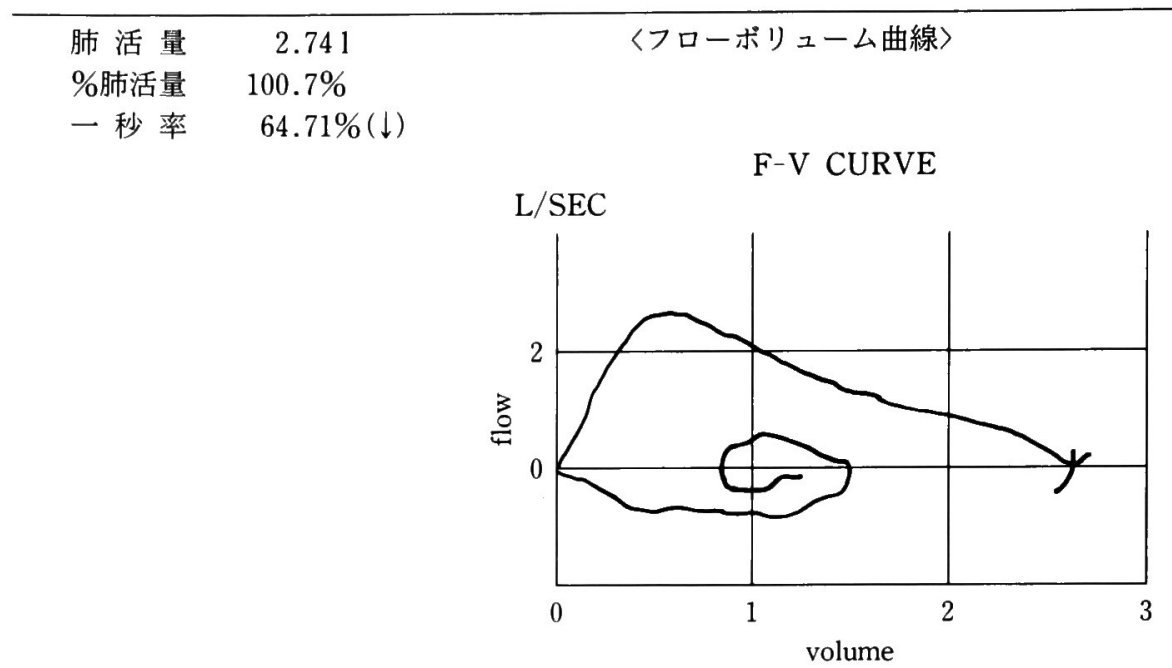

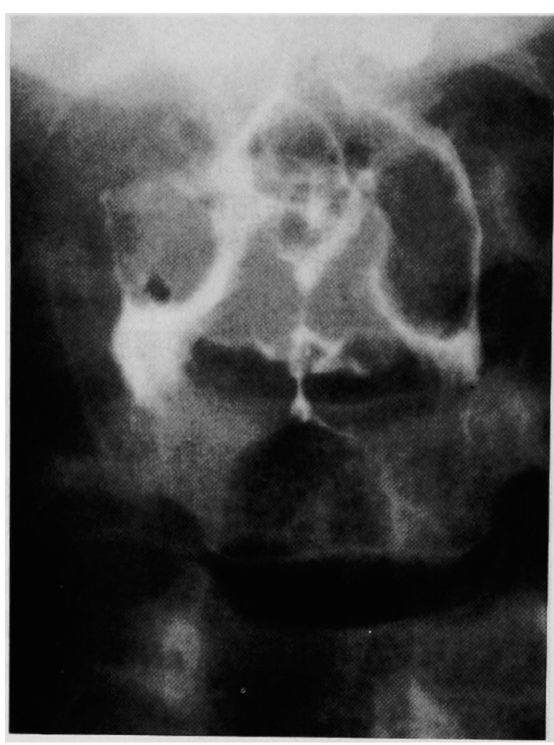

正面

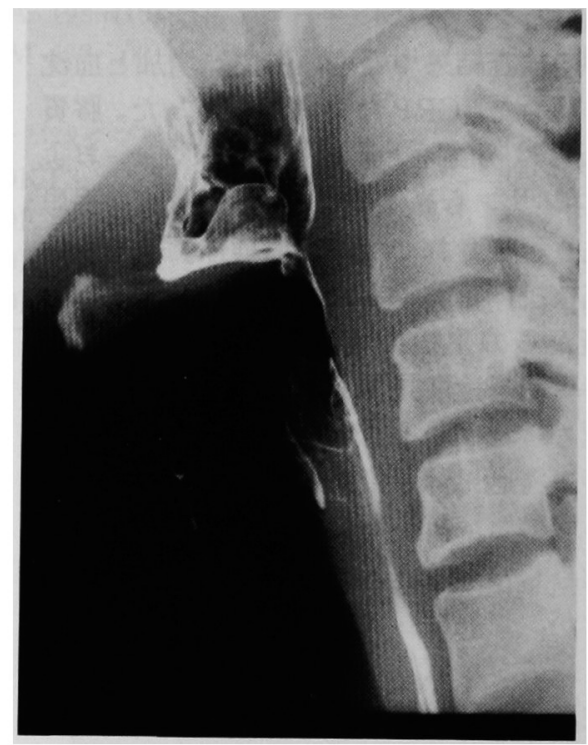

側 面

図 6 喉頭蓋形成術前の造影 X 線検査 喉頭蓋の変形が認められる。

も長期にわたると副作用の心配があり，本症例 でも月経周期の乱れがみられた。

そこでロ腔アフタ性潰瘍やベーチェット病の 東洋医学的治療として古くから用いられ, 有効 とされている温清飲を投与してみたところ, 潰 瘍の増覀が抑えられた。また，ステロイド剂の 局所塗布を併用した場合の月経異常も, この温 清飲を用いるようになって軽減したようであ
る。今後, 温清飲の投与を続けて, しばらく経 過をみていく予定であるが, 再度咽・喉頭狭窄 を来さないよう, 厳重な観察を続ける必要があ ると考えている。

\section{3. 考察}

再発性口腔・咽頭潰瘍は, 約 1 週間で般痕を 残さず治瘾する，「小アフタ型」と呼ばれる小円 


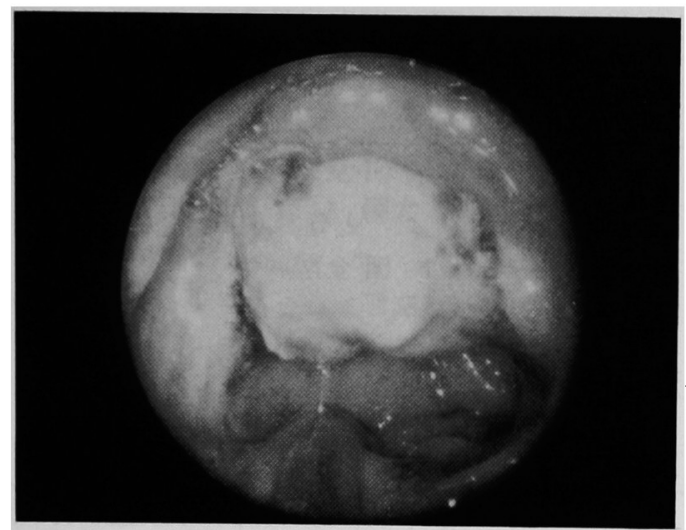

術後 1 週間 (マーゲンゾンデが挿入されている)

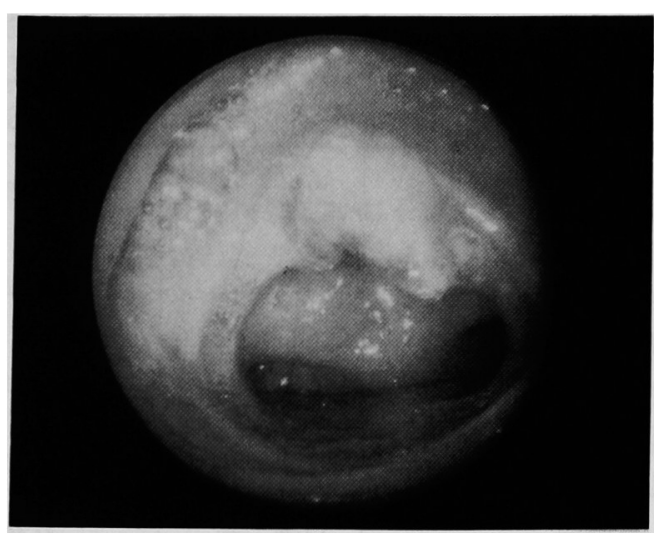

術後 3 週間

図7喉頭蓋形成術後の下咽頭・喉頭所見

術後 1 週間では, 喉頭蓋の腫脹がみられるが, 術後 3 週間めには, 腫脹が改善し, air space が開大した。

形の潰瘍が大部分である。しかし，さらに深い 潰瘍を形成し治癒後に瘢痕を残す「大アフ夕型」 や，小潰瘍が多発し瘾合する「疮疹状潰瘍型」 とよばれるものも時にみられる11,2)。

これらの口腔・咽頭潰瘍は, ベーチェット病 の口腔病変と, 経過・所見ともに識別ができな いとされている3゙。また口腔・咽頭潰瘍がベーチ エット病にほほ必発で, 初発症状としても最も 多く， 口腔・咽頭潰湟を繰り返すうちに数年の 経過ののちにベーチェット病に移行することも あるとされている4)。すなわち再発性の口腔・咽 頭潰瘍には全身的な疾患に進行するものや，全 身的な疾患の部分症状として発現するものも多 く，全身的なチェックも含めて経過を観察する ことが必要な疾患とされている5)。

\section{1）成因および病態}

再発性の口腔咽頭潰瘍もべーチェット病も, その成因および病態は不明で, 消化器異常説, 内分泌障害説，自己免疫疾患やアレルギーのよ うな免疫異常説, 感染症説などのいくつかの仮 説がたてられている。とくに免疫機構の異常が 強く関与しているという考えが近年支持される ようになり, 免疫動態を調べる基礎的実験もい くつか報告されている。

Savage $ら^{6)}$ は潰瘍の経過に伴い潰瘍部の組 織中の Tリンパ球が変化すること, すなわち潰 瘍の急性期に OKT $4 / 8$ 比が低下し, 治瘾期には 上昇することを示している。また Greenspan
ら”は再発性口腔・咽頭潰瘍患者には免疫担当 細胞の不均衡があり,これに感染や外傷が加わ ると，それに対する異常な免疫応答がおこり， それが契機となり潰瘍が生じるとしている。ま た Burnett $ら^{8)}$ は細胞性免疫と液性免疫がとも に本疾患に関与していると報告し, Lindemann ら ${ }^{9)}$ は液性免疫の関与を示している。また, 森川 $ら^{10)}$, 浅井ら ${ }^{(1)}$ による本邦における難治性の多 発性口腔・咽頭潰瘍の症例でも, 免疫グロブリ ンの異常が認められている。

本症例では, 細胞性免疫に関してはリンパ球 サブセットの割合に異常はみられなかったが, 免疫グロブリンの増加，とくに $\operatorname{IgA}$ が高値を示 しており，兔疫系の異常が考えられた。

しかし，この免疫系の異常は何らかの原因に より惹き起こされた二次的なものである可能性 もあり，免疫異常だけでは説明できない点も多 く, 再発性口腔・咽頭潰瘍の病態にはまだ不明 な点が多い。

諸家による再発性口腔・咽頭潰瘍の統計的な 報告(2) 14) をみると, 男性よりも女性に若干多 くなっている。発症は10歳代から20歳代が多い としている。

発症に関与する因子として, Chawda ら ${ }^{12)}$, Ferguson ら ${ }^{13)}$ は精神的ストレスやホルモン異 常, 口内外傷や歯肉の異常をあげ, Axell ら ${ }^{14)}$ は 上気道感染や消化器症状と口腔潰瘍の関係を示 している。また，遺伝関係や家族歴も関与する 
日気食会報, $39(4), 1988$

表 3 再発性咽頭浿瘍から咽・喉頭狭窄をきたした症例

\begin{tabular}{|c|c|c|c|c|}
\hline 報 告 者 & 症 例 & $\begin{array}{l}\text { 潰瘍発症からの } \\
\text { 経 過 }\end{array}$ & 随判症状 & 外科的治療 \\
\hline $\begin{array}{l}\text { T. Kobayashi } \\
\text { et al. }{ }^{20)} \text { ('82) }\end{array}$ & 23歳, 女 & 6 年 & $\begin{array}{c}\text { ベーチェット (不全型) } \\
\text { 陰部, 大腸 }\end{array}$ & $\begin{array}{l}\text { 下咽頭形成 } \\
\text { (有茎皮弁) }\end{array}$ \\
\hline $\begin{array}{r}\text { G. B. Brookes } 21) \\
(' 83)\end{array}$ & 33歳, 男 & 6 年 & ベーチェット $($ 不全型 $)$ & $(-)$ \\
\hline $\begin{array}{l}\text { M. Hanza } \\
{\text { et } \text { al. }^{22)}}^{(' 85)}\end{array}$ & 17歳, 男 & 4 年 & $\begin{array}{c}\text { ベーチェット (不全型) } \\
\text { 陰部, 皮店 }\end{array}$ & $(-)$ \\
\hline 古内ら ${ }^{23)} \quad(' 86)$ & 31歳, 女 & 4 年 & $(-)$ & $(-)$ \\
\hline 自験例 & 43歳, 女 & 2 年 & $(-)$ & $\begin{array}{l}\text { 喉頭蓋形成 } \\
(\text { レーザー) }\end{array}$ \\
\hline
\end{tabular}

とされており ${ }^{15)}$, Nasamba ら ${ }^{16)}$ は常染色体優 性遺伝を疑わせた家族内発症の一家系を報告し ている。また, ベーチェット病では HLA-B5 が 関係するとされており，再発性口腔・咽頭潰場 でもこの傾向があることが報告されてい る17118)。しかし, HLA-B5 の関与は人種により 異なるため, 本症例では調べていない。

本症例は発症が43歳で, これらの報告による 好発年齢よりも高齢であった。家族内での発症 はなく，またストレスやホルモンバランスとの 明確な関係は認められなかった。しかし，43歳 の女性ということで，更年期前であるため多少 の性ホルモンの変化は関与していた可能性があ る。潰瘍の軽快と増悪にとくに決まった周期は なかったため, 経時的なホルモン測定は行って いないが，周期的に悪化がみられる場合には木 ルモンの推移との関係も重要であろう。Ferguson $ら^{13)}$ は, 性ホルモン周期に伴い口腔・ 咽頭潰瘍が変化する場合, 黄体期や妊娠時に寛 解をみ, 月経後や出産直後に再度増悪をきたす ため,ホルモン療法が有効であると述べている。

口腔内および歯牙・歯肉の状態では，本症例 は処置済みの歯牙が多く，感染源となるう歯は なかった。口望内の細菌検查でもとくに異常な 細菌は検出されていない。また歯科治療に用い られた金属のアレルギーを調べるための，歯科 治療用の各金属についての皮膚パッチテストで 特異的な反応は認められなかった。

食物に対するアレルギー反応が本症と関係が あるとの考えもあり ${ }^{19}$ RAST 法で検索したが,
食物アレルギーもはつきりせず，本症例におけ る原因や誘因は依然として明らかでない。さら に下咽頭・喉頭狭窄をきたすまでに急速な悪化 をもたらした原因も不明であるが，上気道感染 や潰瘍を放置するうち，免疫機構の乱れが生じ たのではないかと推察される。

\section{2 ）咽頭潰瘍による下咽頭・喉頭狭寉}

小アフタ型の咽頭潰場の場合には疫痕を残さ ないが，大アフタ型では治瘾後に疲痕を残すこ とは前述した。この瘢痕が生じると, 部位によ つては重篤な機能障害が残る可能性がある。

Hathout $^{5)}$ は再発性咽頭潰瘍の132症例の 40 \%で，口腔粘膜の病変のほかに咽頭後壁や喉頭 蓋, 口蓋垂に二次的な病変が出現したと報告し ている。本症例も初診時には舌と中咽頭右側壁 にあった潰瘍性病変が，再来時には喉頭蓋にま で達しており, 病変が口腔から下咽頭・喉頭へ 進展したものと考えられる。また潰㿠も深く, 大アフタ型で, 治凂後に瘢痕性の狭窄をきたし 嬩下障害や呼吸困難が残った。

このように再発性難治性の咽頭潰瘍から下咽 頭狭窄をきたした症例を文献的にみたところ，

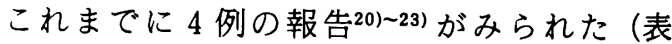
3 )。これらの症例をみると, 潰瘍の発症はいず れも10歳代から 20 歳代で本症の好発年齢に一致 しており, 潰瘍の発症から 4 年ないし 6 年の経 過ののちに下咽頭狭窄の症状，すなわち呼吸困 難と嶼下障害とを訴えるようになっていた。

これらの報告例と本症例とを比較してみる と, 本症例のほうが 43 歳と高齢で, また約 2 年 
表 4 再発性アフタ・潰演の治療

I . 局所的薬物療法

・硝酸銀局所塗布

・ステロイド剤局所塗布

II. 全身的薬物療法

・ステロイド剤

・非ステロイド系消炎剤

- 漢方療法

・コルヒチン製剤

・抗アレルギー剤

・兔疫抑制剂

・免疫調節剂

・血小板凝集阻止剂

間で狭窄症状が出現しており, 進行が急激であ ったといえる。一般に自己免疫疾患の好発年齢 も若年層であること，また内分泌的な変動が妊 娠や出産を契機に悪化することから考えて, 本 症例ではこれらの因子の関与が少なく，何か別 の因子が発症の引き金となったと考えることも できるであろう。

下咽頭狭窄をきたした報告例 4 例のうち 3 例 が陰部潰瘍や眼症状などの随伴症状があり, べ 一チェット病の不全型と診断されている。本症 例では, 現在のところは眼症状, 皮膚症状や陰 部潰瘍もなく, ベーチェット病とは診断されて いないが，狭窄をきたすまでの広範で重篤な潰 瘍を繰り返しおこしていることからも, 咽頭潰 瘍が全身的な疾患の一部である可能性も強く, 厳重な経過観察が必要であると思われる。

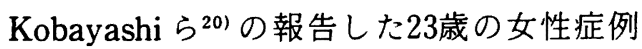
では狭窄を改善するため, 頸部有茎皮弁を用い る下咽頭形成術を施行し, 良好な結果を得たと している。その他の 3 例ではステロイド剤の全 身投与で狭窄症状が寛解したと報告されている が, Brookes ${ }^{21)}$ は, いずれ狭窄がさらに進行す れば皮弁を用いる下咽頭形成術が必要であろう と述べている。

われわれの症例では痽痕狭窄の最も強い部分 が喉頭蓋周囲であったことから， $\mathrm{CO}_{2}$ レーザー で喉頭蓋周囲の瘢痕を切離し，除去することに よって咽・喉頭腔を拡大することができた。レ ーザーを用いたため, 術創部からの出血がなく 十分な視野を得ることができ，手術時間も短縮
することができた。しかし，今後さらに炎症を 繰り返し, 痒痕がより広範囲にまで進行した場 合，やはり皮弁を用いる下咽頭形成も必要にな ってくるであろう。

本疾患は良性疾患ではあるが，このように瘢 痕が広範囲にわたり，下咽頭・喉頭にまで進行 すると気道や食道への影響がでてくること，そ れが比較的若年者で, しかも数年のうちに狭窄 が出現すること, 急速に増悪することがあるこ とからも厳重に経過を観察し, 症状の推移に留 意し, 早期に適切な処置をとる必要があると思 われた。

\section{3 ) 治}

本疾患は原因が明らかでなく，種々の因子が 関与している可能性もあり, 根本的な有効な治 療法はいまのところない。一般的に局所におけ る免疫応答を抑制する意味で, 対症的にステロ イド剤を用いることが多い。

治療法は局所療法と全身療法の 2 つに大別さ れる(表 4)。小アフ夕型など軽症の場合は, 局 所療法として硝酸銀の局所塗布やステロイドの 口腔粘膜付着型治療剤が用いられ, 局所療法の みで治瘣するのが普通である。しかし，ステロ イド剤の場合たとえ局所塗布でも，長期にわた り広範に塗布した場合粘膜からの吸収や，口腔 粘膜に付着しなかった薬剤を嚥下することも多 く, 副作用が問題となってくる。本症例でも退 院後の外来経過観察中に口腔内にステロイド軟 高を塗布し続けていたところ一時月経周期の乱 れを生じた。この副作用を防止するため, 非ス テロイド系抗炎症剂を主剂とした口腔粘膜付着 型治療剂が開発され，臨床応用で有効であった との報告もみられる ${ }^{24)}$ 。また口腔・咽頭粘膜への 薬剤の付着性も今後さらに改良が必要と思われ る。

一方, 再発を頑固に繰り返したり, 大アフタ 型となり, 病変の範囲も広く, 症状も強いもの や，全身疾患が疑われる場合には全身療法が行 われる。

薬剤の全身投与に関しては，やはり本疾患の 病因がはっきりしないため定説はなく, 病因と していくつかあげられている仮説にもとづいた 治療が試みられている（表 4)。

ステロイド剤の全身投与は，免疫反応を抑え 
消炎効果が強く，病状の急性期には非常に有効 で, 比較的即効性もある。しかし，長期にわた る使用は副作用の点から望ましくなく維持療法 には適さない。

ステロイド剤以外の薬剤では，消炎・鎖痛作 用を期待して, 非ステロイド系消炎剂が用いら れる。免疫反応を抑制するという意味では, 白 血球機能抑制剂であるコルヒチンや，免疫抑制 剤であるサイクロフォスファマイド・サイクロ スポリン Aが用いられることもあるが，これら の薬剤も副作用に十分注意しなくてはならな い。また，本疾患をアレルギー反応と考える立 場から抗アレルギー剂が, 液性免疫異常と考え る立場から免疫グロブリン製剤が有効であると されている。

さらに本疾患を漢方医学的立場から考える方 向もある。東洋では古くから, 再発性のアフ夕 やベーチェット病の口腔症状に対して, 温清飲 が投与されており，有効性が認められている。 これは四物湯と黄連解毒湯を合わせたもので, 当帰, 生地黄, 苟薬, 川芎, 黄芩, 黄柏, 黄連 および山柅子という 8 種の生薬から構成され,

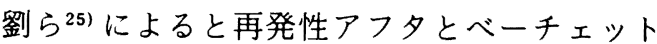
病の口腔病変の治療において, $79 \%$ の有効率が 得られたとしている。またその薬理作用につい ても言及しており, 温清飲の黄連解毒湯には免 疫賦活作用があり免疫能低下によるアフ夕に対 して有効で, 一方当帰, 苟薬, 川芦, 黄芩は液 性免疫能を抑制する作用があり, 自己免疫疾患 やアレルギーによるアフタに有効であるとして いる。

われわれの症例でも，ステロイド剤の内服を やめ, まず抗アレルギー剤として塩酸アゼラス チンやヒスタミン加ヒト $\gamma$-グロブリン製剤を 投与してみたが，効果はみられなかった。つぎ に温清飲を投与したところ，潰瘍の進行が抑制 され有効であると思われた。ステロイドの局所 塗布と併用しながら，現在継続して投与中であ る。今後しばらくこの治療を続け, 免疫学的パ ラメーターの変化をみながら, 経過を観察する 予定である。

\section{4. 予 後}

以上のように, 再発性口腔咽頭潰瘍の病因や
治療法にはまだ不明な点が多く，また多くの因 子が関与している可能性があり，根治させるこ とが困難な疾患である。

本症例も現在のところは一応寛解状態である が，口腔内には相変わらずアフタが存在してお り, 感染・ストレス・ホルモンバランスによっ て病状が再度急激に悪化する恐れも十分ある。 その場合, 食道系・気道系への障害は一層大き くなることが予測されるので, 疾患そのものは 良性であっても，慎重に経過を観察し，早期に 適切な処置を取れる体制になくてはならない。

またべーチェット病へ移行したものの予後は 悪く, 血管系, 神経系, 消化器系の致命的な合 併症をおこすことがあり，本症例でも今後，眼 症状, 消化器症状などの出現に注意していくこ とが必要と思われた。

\section{5.まとめ}

1 ）原因不明の再発性難治性口腔・咽頭潰瘍 から下咽頭・喉頭狭窄をきたした43歳女性の 1 症例を報告した。

2 ）免疫系の異常の関与が考えられ，ベーチ エット病のような全身疾患の一部である可能性 も示唆された。

3) $\mathrm{CO}_{2}$ レーザーを用いて下咽頭喉頭狭窄 症状の寛解をみたが, 疾患そのものの根本的治 療が現在のところなく，良性疾患ではあるもの の厳重な経過観察が必要と思われた。

本論文の要旨は昭和 62 年 10 月第39回日本気管食道 科学会で報告した。

稿を終えるにあたり，本症例の観察にあたり御指 導いただいた横浜市立大学医学部耳鼻咽喉科学教室 の諸兄姉に心から感謝致します。

\section{文献}

1) Cooke, B.E.D. : Recurrent oral ulceration. Br. J. Dermatol., $81:$ 159-161, 1969.

2 ) Merchant, M.S., et al.: Recurrent aphthous stomatitis and herpetiform ulcerations. J. Michigan. Dent. Assoc., 66 : 357-363, 1984.

3 ) Graykowski, E.A., et al. : Recurrent aphthous stomatitis. Clinical, therapeutic, histopathologic, and hypersensitivity aspects. JAMA, 196:129-136, 1966.

4 ) 橋本喬史・他：日常診療の実際 ベーチェット 病. 治療, $69: 1431-1435,1987$. 
5) Hathout, Y.M.: Recurrent aphthous stomatitis: otolaryngological interest. Revue de Laryngologie, $107:$ 127-129, 1986.

6 ) Savage, N.W., et al.: T-lymphocyte subset changes in recurrent aphthous stomatitis. Oral Surg., $60: 175-181,1985$.

7 ) Greenspan, J.S., et al. : Lymphocyte function in recurrent aphthous ulceration. J. Oral. Pathol., 14 : 592-602, 1985.

8 ) Burnett, P.R., et al. : Lytic effect of serum and mononuclear leukocytes on oral epithelial cells in recurrent aphthous stomatitis. Clin. Immunol. Immunopathol., $34:$ 197-204, 1985.

9 ) Lindemann, R.A., et al. : Secretory and serum antibody responses to oral bacterial antigens associated with recurrent aphthous ulceration. J. Oral Med., $41: 75-78,1986$.

10）森川清見・他：悪性疾患を疑わせた難治性の多 発性口腔咽頭潰瘍。耳展, $27 ： 41-45,1984$.

11）浅井秀子・他：再発性の口腔, 咽喉頭潰瘍の 3 症例. 耳鼻臨床, $78: 1328-1333,1985$.

12) Chawda, J.G., et al.: Recurrent aphthous ulcer. Ann. Dent. N.S., 43:14-17, 1984.

13) Ferguson, M.M., et al.: An epidemiological study of factors associated with recurrent aphthae in women. J. Oral Med., $39: 212-217$, 1984.

14) Axell, T., et al. : The occurrence of recurrent aphthous ulcers in an adult Swedish population. Acta Odontol. Scand., 43 : 121-125, 1985.

15) Rennie, J.S., et al.: Recurrent aphthous stomatitis. Br. Dent. J., 159: 361-367, 1985.
16) Nasamba, C., et al.: Inheritance of recurrent aphthous ulceration of the mouth. J. Laryngol. Otol., 100:361-362, 1986.

17) Savage, N.W., et al.: Expression of class I and class II major histocompatibility complex antigens on epithelial cells in recurrent aphthous stomatitis. J. Oral Pathol., 15 : 191$195,1985$.

18) Gallina, G., et al. : HLA-A, B, C, DR, MT, and $\mathrm{MB}$ antigens in recurrent aphthous stomatitis. Oral Surg., $59: 364-370,1985$.

19) Hindle, M.O., et al. : Food allergy or intolerance in severe recurrent aphthous ulceration of the mouth. Br. Med. J., $292: 1237-1238$, 1986.

20) Kobayashi, T., et al. : Ulceration and stenosis of the hypopharynx and its surgical management. Head \& Neck Surg., $5: 65-69,1982$.

21) Brookes, G.B.: Pharyngeal stenosis in Behçet's syndrome. Arch. Otolaryngol., 109 : 338-340, 1983.

22) Hanza, M., et al. : Stenose pharyngee dans un cas de maladie de Behçet. Ann. Oto-Laryng., $102: 465-467,1985$.

23）古内一郎・他：再発性潰瘍による下咽頭狭窄症 例. JOHNS, 2:621-625, 1986.

24）松田 登・他：TN-18G による再発性アフタの 治療成績. 新薬と臨床, $33: 397-404,1984$.

25）劉 瑞梅・他：温清飲の薬理作用及び再発性ア フ夕に対する効果. 和漢医薬学会誌, $2: 698$ 699, 1985 